\title{
MENINGKATKAN PRESTASI BELAJAR IPS DENGAN PENGGUNAAN MEDIA VIDEO PADA SISWA KELAS V A SD NEGERI 2 TANJUNG
}

\author{
Dadah Kusmiati \\ SD Negeri 2 Tanjung, Jl. Air Tanjung, Kawalu, Tasikmalaya, Indonesia \\ Email: dadahkusmiati961@gmail.com
}

\begin{abstract}
As a motivator, the teacher must be able to arouse students' motivation to obtain a succesful student' activities in the learning process. To stimulate student activity in the learning process is by using interesting media, in particular video media. This study aims to improve students' learning achievement of Social Sciences in grade V A SD Negeri 2 Tanjung Kota Tasikmalaya by using video media. This classroom action research involves 25 students in class V A SD Negeri 2 Tanjung Kota Tasikmalaya. Data collection techniques utilized observation, tests, and documentation. The research instrument employed observation sheets, written tests and documentation. The data obtained from students test are analysed by using quantitative descriptive. The results of this study indicate that the use of video media can improve the students' learning achievement of Social Sciences in grade V A SD Negeri 2 Tanjung Kota Tasikmalaya. In the precycle, there are 8 students (32\%) who are complete. It increased in the first cycle by 14 students ( $56 \%)$, and followed by 21 students (84\%) in the second cycle Meanwhile, students who has not been complete have decreased. There were 17 students (68\%) who had not yet been complete in the pre-cycle. It is follwed by 11 students (44,\%) in the first cycle; and it decreased again by 4 students or $16 \%$ in the second cycle. Students who have not been complete are given additional assignments in the form of memorizing the text of the proclamation and reading it in front of the class. The mean score of the class is also increased by 58.64 in the pre-action. Meanwhile, in the first cycle, it increased to 65.84 and followed by 83 in the second cycle.
\end{abstract}

Keywords: Learning achievement, Social Sciences, Video Media, Class V Students

\begin{abstract}
ABSTRAK
Sebagai motivator, guru harus mampu membangkitkan motivasi para siswa agar aktivitas mereka dalam proses pembelajaran berhasil dengan baik. Salah satu cara untuk membangkitkan aktivitas para siswa dalam proses pembelajaran adalah menggunakan media yang menarik, salah satunya adalah menggunakan media video. Penelitian ini bertujuan untuk meningkatkan prestasi belajar IPS terhadap siswa kelas V A SD Negeri 2 Tanjung Kota Tasikmalaya dengan menggunakan media video. Penelitian tindakan kelas ini melibatkan 25 siswa sebagai subjek penelitian yang berasal dari kelas V A SD Negeri 2 Tanjung Kota Tasikmalaya. Teknik pengumpulan data menggunakan observasi, tes, dan dokumentasi. Sedangkan Instrumen penelitian menggunakan lembar observasi, tes tertulis dan dokumentasi. Data dari tes siswa di analisis secara deskriptif kuantitatif. Hasil penelitian ini menunjukkan bahwa bahwa penggunaan media video dapat meningkatkan prestasi belajar IPS terhadap siswa kelas V A SD Negeri 2 Tanjung Kota Tasikmalaya. Pada pra siklus, siswa yang tuntas ada 8 siswa (32\%), kemudian meningkat pada siklus I sebesar 14 siswa (56\%). Pada siklus II terdapat peningkatan lagi sebesar 21 siswa (84\%). Sedangkan siswa yang belum tuntas mengalami penurunan pada pra siklus sebanyak 17 siswa (68\%), pada siklus I turun menjadi 11 siswa (44\%) dan pada siklus II mengalami penurunan kembali sebanyak 4 siswa (16\%). Siswa yang belum tuntas diberikan tugas tambahan berupa menghafalkan teks proklamasi dan dibacakan di depan kelas. Rata- rata kelas juga mengalami peningkatan yaitu pra tindakan sebesar 58,64, siklus I meningkat sebesar 65,84 dan pada siklus II meningkat kembali sebesar 83.
\end{abstract}

Kata Kunci: Prestasi belajar, IPS, Media Video, Siswa Kelas V

Cara sitasi: Kusmiati, D. (2021). Meningkatkan Prestasi Belajar IPS dengan Penggunaan Media Video pada Siswa Kelas V A SD Negeri 2 Tanjung. J-KIP (Jurnal Keguruan dan IImu Pendidikan), 2 (1), 27-32. 


\section{PENDAHULUAN}

Manusia diciptakan oleh Tuhan dengan membawa fitrah yang merdeka, mempunyai hak dan kebebasan yang telah melekat pada dirinya (Sudijono, 2011). Oleh karena itu dalam kehidupan, manusia mempunyai hak untuk hidup, hak bersuara, kebebasan mengemukakan pendapat, dan hak yang lainnya selama kebebasan dan hak tersebut tidak bertentangan dengan norma sosial agama. Begitu juga dalam kegiatan belajar mengajar, dalam hal ini siswa mempunyai hak dan kebebasan untuk bersuara, berpendapat atau beragumen di dalam kelas yang berkaitan dengan materi pelajaran di kelas. Saat berlangsungnya Kegiatan Belajar Mengajar (KBM) seharusnya yang aktif bukanlah gurunya saja, dimana siswa hanya dianggap sebagai suatu benda yang pasif, yang hanya mendengarkan dan mematuhi apa yang disampaikan oleh guru.

Menurut Sugihartono, et. al. (2007) pembelajaran merupakan suatu upaya yang dilakukan dengan sengaja oleh pendidik untuk menyampaikan ilmu pengetahuan, mengorganisasi, dan menciptakan sistem lingkungan dengan berbagai model serta metode sehingga siswa dapat melakukan kegiatan belajar secara efektif dan efisien serta mendapat hasil optimal. Pendidik harus kreatif dan inovatif dalam menerapkan strategi pembelajaran sehingga siswa mampu menggunakan kemampuan berpikir tingkat tinggi (Afifah, et. al. 2020). Belajar dapat dilakukan di mana saja baik di keluarga, lingkungan atau masyarakat, maupun sekolah. Sekolah merupakan salah satu lembaga resmi yang menyelenggarakan kegiatan belajar. Salah satu pembelajaran yang diajarkan di sekolah dasar adalah pembelajaran IPS.

IImu Pengetahuan Sosial adalah perwujudan dari suatu pendekatan interdisipliner dari ilmu sosial. la merupakan integrasi dari berbagai cabang ilmu sosial yakni sosiologi, antropologi budaya, psikologi, sejarah, geografi, ekonomi, ilmu politik, dan ekologi manusia, yang diformulasikan untuk tujuan instruksional dengan materi dan tujuan yang disederhanakan agar mudah dipelajari. IImu Pengetahuan Sosial merupakan pelajaran ilmu-ilmu sosial yang disederhanakan untuk pendidikan tingkat SD sampai SMA.

Pola pembelajaran IPS menekankan pada unsur pendidikan dan pembekalan pada siswa. Penekanan pembelajarannya bukan sebatas pada upaya mentransfer sejumlah konsep yang bersifat hafalan belaka kepada siswa, melainkan terletak pada upaya agar siswa mampu menjadikan apa yang telah dipelajarinya sebagai bekal dalam memahami dan ikut serta dalam menjalani kehidupan di masyarakat, serta sebagai bekal bagi dirinya untuk melanjutkan ke jenjang yang lebih tinggi. Melalui ilmu pengetahuan tersebut pengetahuan dan wawasan serta keterampilan anak akan semakin bertambah dalam menyelesaikan masalah yang ada di sekitarnya.

Pada saat ini pembelajaran IPS masih berorientasi pada guru (Teacher Centered) dan proses pembelajaran yang dilakukan oleh banyak tenaga pendidik saat ini cenderung pada pencapaian target materi kurikulum (Arsyad, 2013). Pengalaman penulis di lapangan bahwa pelaksanaan pembelajaran IPS masih berpusat pada guru (teacher centered). Berdasar data yang diperoleh, pada semester ganjil tahun ajaran 2018/2019 dari 25 siswa di siswa kelas V SD Negeri 2 Tanjung Kota Tasikmalaya tersebut rata- rata nilai TKM (Tes Kendali Mutu) asli siswa adalah 58,64. Kriteria Ketuntasan Minimal (KKM) untuk mata pelajaran IPS yaitu $\geq 70$. Dari 25 siswa tersebut siswa yang di atas KKM ada 8 (32\%) siswa dan yang masih di bawah KKM ada 17 (68\%) siswa.

Suasana pembelajaran yang diharapkan adalah menjadikan siswa lebih banyak berperan (kreatif) karena peran guru adalah sebagai sumber belajar, fasilitator, pengelola, demonstrator, pembimbing, dan evaluator (Sanjaya, 2006). Sebagai motivator guru harus mampu membangkitkan motivasi siswa agar aktivitas siswa dalam proses pembelajaran berhasil dengan baik. Salah satu cara untuk membangkitkan aktivitas siswa dalam proses pembelajaran adalah dengan mengganti cara / model pembelajaran yang selama ini tidak diminati lagi oleh siswa dengan menggunakan media yang menarik agar siswa memusatkan perhatian pada materi yang sedang mereka pelajari (Prastowo, 2013). Salah satu media pembelajaran yang menarik adalah media video. 
Berdasarkan latar belakang yang telah diuraikan maka rumusan masalah dari penelitian ini adalah apakah terdapat peningkatan prestasi belajar IPS dengan penggunaan media video pada siswa kelas V A SD Negeri 2 Tanjung?.

\section{METODE PENELITIAN}

Peneliatian tindakan kelas ini dilaksanakan pada siswa kelas V A SD Negeri 2 Tanjung Kota Tasikmalaya dalam dua siklus, dimana dalam setiap siklus dilaksanakan sebanyak dua kali pertemuan, pelaksanaan pembelajaran diawali dengan tes pra siklus yang dilaksanakan pada minggu pertama September 2018 hal ini dilakukan untuk mengetahui kemampuan dan nilai belajar siswa dalam pelaksanaan pembelajaran, dilanjutkan pada pelaksanaan pembelajaran siklus I yang dilaksanakan pada tanggal 25 dan 27 September 2018 sedangkan siklus II dilaksanakan pada tanggal 2 dan 4 Oktober 2018.

Pada model Kemmis \& Mc Taggart komponen tindakan dan observasi menjadi satu komponen karena kedua kegiatan ini dilakukan secara simultan dan selanjutnya penelitian ini dilaksanakan dalam langkah siklus yaitu perencanaan, tindakan dan observasi, serta refleksi (Sugiyono, 2010).

1. Perencanaan

Arikunto, et. al. (2009) menjelaskan bahwa dalam tahap penyusunan rancangan ini peneliti menentukan fokus peristiwa yang perlu menjadi perhatian untuk diamati, kemudian membuat sebuah instrumen pengamatan.

Berdasarkan uraian tersebut maka dalam tahap perencanaan ini guru menyiapkan segala sesuatu yang diperlukan. Setelah mengetahui permasalahan yang terdapat dalam kelas maka dengan menggunakan media audio visual dapat meningkatkan prestasi belajar IPS siswa kelas V A SD Negeri 2 Tanjung Kota Tasikmalaya. Tahap perencanaan dalam penelitian ini adalah sebagai berikut.

a. Menyusun RPP untuk perencanaan proses pembelajaran.

b. Membuat media video berdasarkan pokok bahasan.

c. Menyiapkan materi yang akan menjadi bahan evaluasi.

2. Pelaksanaan Tindakan dan Observasi

Pelaksanaan tindakan disesuaikan dengan rencana pelaksanaan pembelajaran. Kegiatan yang dilakukan dibagi dalam kegiatan awal, kegiatan inti, dan kegiatan akhir dan sesuai dengan langkah- langkah penerapan media video dalam pembelajaran. Pada kegiatan akhir setiap siklus siswa mengerjakan soal evaluasi untuk mengukur prestasi belajarnya. Selanjutnya siswa melakukan refleksi mengenai pelajaran yang baru saja dipelajari. Kegiatan terakhir guru menjelaskan materi yang akan dipelajari selanjutnya.

Kegiatan observasi dilaksanakan untuk seluruh proses pembelajaran yang dilakukan guru dan siswa, baik sebelum pembelajaran, saat pembelajaran maupun setelah pembelajaran. Hasil dari observasi ini menjadi dokumen penting dan menjadi dasar dalam pelaksanaan tindakan siklus berikutnya.

Arikunto, et. al. (2009) pengamatan dan pelaksanaan tindakan tidak dapat dipisahkan karena pengamatan dilakukan pada saat melakukan tindakan. Oleh karena itu dalam kegiatan observasi atau pengamatan dilakukan oleh pengamat.

3. Refleksi

Kegiatan refleksi merupakan kegiatan untuk mengemukakan kembali apa yang sudah dilakukan. Kegiatan refleksi dilakukan secara terbuka dan fair setelah melakukan tindakan dengan mengkaji dan menganalisis data yang diperoleh saat melakukan tindakan penelitian. Dari analisis data tersebut diidentifikasi dan disimpulkan untuk tindak lanjut perbaikan tindakan. Apabila hasil dari tindakan siklus pertama belum sesuai dengan tujuan pembelajaran dan dirasa masih perlu diperbaiki maka perlu membuat revisi pada rencana tindakan yang kemudian dibuat 
kembali rencana tindakan yang baru dengan mengacu pada hasil refleksi yang sudah dilaksanakan.

\section{HASIL DAN PEMBAHASAN}

Penelitian tindakan kelas ini terdiri dari dua siklus, setiap siklus terdiri dari dua kali pertemuan. Pembahasan peningkatan prestasi belajar pada siklus I dan siklus II sebagai berikut.

1. Peningkatan Prestasi Belajar Siklus I

Pada pelaksanaan pembelajaran pra siklus nilai belajar siswa terlihat masih rendah dari 25 siswa terdapat 8 orang siswa yang tuntas atau sebesar (32\%) sedangkan yang belum tuntas sebanyak 17 orang siswa atau sebesar $(68 \%)$, dengan nilai rata- rata kelas sebesar 58,64. Kemudian penulis merancang sebuah pembelajaran menggunakan video. Setelah penggunaan video hasil evaluasi pada siklus I siswa yang tuntas sebanyak 14 orang siswa atau sebesar $56 \%$ sedangkan yang tidak tuntas sebanyak 11 orang siswa atau sebesar $44 \%$, dengan nilai rata-rata sebesar 65,84. siklus I terdapat peningkatan prestasi belajar siswa sebesar 7,2 (dari pra siklus 58,64 menjadi 65,84). Pada penelitian siklus I peningkatan belum sesuai dengan indikator keberhasilan yaitu sebesar $75 \%$ dari seluruh siswa mencapai $\mathrm{KKM}$, sehingga penulis membuat rencana pelaksanaan untuk siklus berikutnya dengan tujuan untuk memperbaiki prestasi belajar siswa yang belum mencapai KKM.

2. Peningkatan Prestasi Belajar Siklus II

Pada siklus II nilai belajar siswa mengalami peningkatan secara signifikan, hal ini terlihat dari siswa yang tuntas sebanyak 22 orang siswa atau sebesar $84 \%$ sedangkan siswa yang tidak tuntas sebanyak 4 orang siswa atau sebesar $16 \%$, dengan nilai rata-rata sebesar 83 . Dari hasil evaluasi siklus II terdapat peningkatan prestasi belajar siswa sebesar 24,36 (dari pra siklus sebesar 58,64 menjadi 83 pada siklus II). Pada siklus II peningkatan sudah sesuai dengan indikator keberhasilan yaitu sebesar $75 \%$ dari seluruh siswa mencapai KKM, sehingga penulis membuat keputusan bahwa penelitian pada siklus II dianggap sudah berhasil dan tidak dilanjutkan ke siklus berikutnya.

Berdasarkan hasil evaluasi penelitian menunjukkan bahwa media video dapat meningkatkan prestasi belajar IPS yang senada dengan hasil penelitian Rahmawati (2013). Hal tersebut sesuai dengan teori yang dikemukakan oleh Gagne bahwa belajar dimulai dari hal yang paling sederhana dilanjutkan pada hal yang lebih kompleks sampai pada tipe belajar yang lebih tinggi serta teori dari Piaget tentang tahap perkembangan kognitif anak pada usia 7- 11 tahun merupakan tahap operasional konkret, anak akan lebih jelas tentang sebuah informasi jika dia dalam memahami informasi tersebut mulai dari hal yang konkret meningkat ke hal yang abstrak dan dalam memahami informasi menggunakan berbagai indera, maka kesan yang ditimbulkan akan lama dan menimbulkan kesan yang membekas pada anak (Sudijono, 2011).

Pelaksanaan tindakan disesuaikan dengan rencana pelaksanaan pembelajaran yang sudah disusun. Kegiatan dilakukan berdasarkan pada skenario pembelajaran yang telah direncanakan dengan tujuan agar pembelajaran yang dilakukan mampu mengembangkan dan meningkatkan prestasi belajar siswa sesuai pokok bahasan yang telah ditentukan dan disepakati untuk dikaji dengan media video. Kegiatan yang dilakukan dibagi dalam kegiatan awal, kegiatan inti, dan kegiatan akhir dan sesuai dengan langkah- langkah penerapan media video dalam pembelajaran. Pada kegiatan awal siswa disapa oleh guru, berdoa bersama, kemudian guru melakukan presensi dan mengingatkan siswa tentang aturan dalam pembelajaran serta mengajak siswa mengulang materi yang lalu.

Kegiatan inti meliputi siswa mendengarkan penjelasan dari guru tentang tujuan pembelajaran kemudian siswa diberi penjelasan agar memperhatikan video yang ditayangkan. Kegiatan selanjutnya yaitu siswa melihat video dan melakukan diskusi tentang materi yang 
ditayangkan lewat video, kemudian siswa membacakan hasil diskusi. Sebelum kegiatan akhir, siswa diberi penegasan oleh guru tentang materi yang baru saja dipelajari dan mengajak siswa membuat kesimpulan dan rangkuman materi.

Pada kegiatan akhir setiap siklus siswa mengerjakan soal evaluasi untuk mengukur prestasi belajarnya. Selanjutnya siswa melakukan refleksi mengenai pelajaran yang baru saja dipelajari. Kegiatan terakhir guru menjelaskan materi yang akan dipelajari selanjutnya.

\section{KESIMPULAN}

Berdasarkan penelitian diperoleh bahwa penggunaan media video dapat meningkatkan prestasi belajar IPS pada siswa kelas V A SD Negeri 2 Tanjung Kota Tasikmalaya. Pada pra siklus siswa yang tuntas ada 8 siswa (32\%) kemudian meningkat pada siklus I sebesar 14 siswa (56\%) pada siklus II mengalami peningkatan lagi sebesar 21 siswa atau (84\%). Sedangkan siswa yang belum tuntas mengalami penurunan. Siswa yang belum tuntas pada pra siklus sebanyak 17 siswa atau $68 \%$, pada siklus I turun menjadi 11 siswa atau $44 \%$ dan pada siklus II mengalami penurunan kembali sebanyak 4 siswa atau $16 \%$. Siswa yang belum tuntas diberikan tugas tambahan dari guru berupa menghafalkan teks proklamasi dan dibacakan di depan kelas. Rata- rata kelas juga mengalami peningkatan yaitu pra tindakan sebesaar 58,64, pada siklus I meningkat menjadi 65,84 dan pada siklus II meningkat kembali menjadi 83. Peningkatan prestasi belajar tidak hanya karena menggunakan media audio visual, tetapi pemberian reward dan motivasi juga berpengaruh terhadap peningkatan prestasi belajar.

Saran yang dapat disampaikan dengan hasil penelitian ini adalah untuk guru yaitu penciptaan suasana kelas yang menyenangkan akan membantu siswa dalam memahami materi pelajaran dan penggunaan media video dapat digunakan sebagai salah satu cara variatif yang dapat digunakan guru agar proses pembelajaran berjalan dengan menyenangkan.

\section{REKOMENDASI}

Penggunaan media video perlu dikembangkan agar menjadi sarana dan prasarana yang dapat menunjang terwujudnya pembelajaran yang aktif, kreatif, inovatif dan menyenangkan sehingga hasil yang diperoleh siswa serta kualitas sekolah dapat terus meningkat.

\section{UCAPAN TERIMAKASIH}

Terima kasih kepada kepala SD Negeri 2 Tanjung Kota Tasikmalaya yang telah memberikan izin pada pelaksanaan penelitian ini.

\section{DAFTAR PUSTAKA}

Afifah, A. N., Ilmiyati, N., \& Toto. (2020). Pengaruh Model Project Based Learning (PjBL) dengan Pendekatan STEM Terhadap Penguasaan Konsep dan Keterampilan Berpikir Kritis Siswa. J-KIP (Jurnal Keguruan dan IImu Pendidikan), 1 (2), 33-40.

Arikunto, S., Suhardjono \& Supardi. (2009). Penelitian Tindakan Kelas. Jakarta: Bumi Aksara.

Arsyad, A. (2013). Media Pembelajaran. Jakarta: Rajawali Press.

Prastowo, A. (2013). Panduan Kreatif Membuat Bahan Ajar Inovatif. Yogyakarta: Diva Press.

Rahmawati, L. Y. (2013). Peningkatan Motivasi dan Prestasi Belajar IPS Siswa Kelas VB SD Kanisius Sengkan dengan Media Audio Visual. Skripsi. Yogyakarta: Universitas Sanata Dharma. 
Sanjaya, W. (2007). Strategi Pembelajaran Berorientasi Standar Proses Pendidikan. Jakarta: Prenada Media Group.

Sudijono, A. (2011). Pengantar Evaluasi Pendidikan. Jakarta: Rajawali Pers.

Sugihartono., Fathiyah, K. N., Harahap, F., Setiawati, F. A., \& Nurhayati, S. R. (2007). Psikologi Pendidikan. Yogyakarta: UNY Press.

Sugiyono. (2010). Metode Penelitian Pendidikan; Pendekatan Kualitatif, Kuantitatif, dan $R \& D$. Bandung: Alfabeta. 